\title{
IMPLIKASI PENAFSIRAN UNDANG-UNDANG OLEH HAKIM PRAPERADILAN DALAM PERKARA TINDAK PIDANA KORUPSI
}

\author{
Yusi Amdani* \\ Bagian Hukum Pidana, Fakultas Hukum Universitas Samudra, Langsa, Aceh \\ Jalan Meurandeh, Kecamatan Langsa Lama, Kota Langsa Aceh, \\ Nanggroe Aceh Darussalam 24416
}

\section{Abstract}

The judge in deciding a case can perform all the legal interpretation is not explicitly defined in the legislation. On the basis of any decision that has been set by the judge, then the decision must be accountable. But in Decision No:04/Pid.Prap/2015/PN.Jkt.Sel, Budi Gunawan pretrial matters related to the Commission, the judge has made a legal interpretation considered contrary to the Criminal Code itself. Judge did interpretation of the Code of Criminal Procedure, on the status of Budi Gunawan as a suspect corruption. The decision has weak the authority of the Commission and the bad in the criminal justice system.

Keywords: interpretation, pretrial, corruption.

\section{Intisari}

Hakim dalam memutuskan suatu perkara dapat melakukan penafsiran hukum sepanjang belum ditentukan secara tegas dalam peraturan perundang-undangan. Atas dasar setiap putusan yang telah ditetapkan oleh hakim, maka putusan tersebut harus dapat dipertanggungjawabkan. Namun dalam Putusan No: 04/Pid. Prap/2015/PN.Jkt.Sel, terkait perkara praperadilan Budi Gunawan terhadap KPK, hakim telah melakukan penafsiran hukum yang dinilai bertentangan dengan KUHAP sendiri. Hakim melakukan penafsiran terhadap KUHAP, atas status Budi Gunawan sebagai tersangka korupsi. Putusan tersebut telah melemahkan kewenangan KPK dan berakibat buruk dalam sistem peradilan pidana.

Kata Kunci: penafsiran, praperadilan, tindak pidana korupsi.

\section{Pokok Muatan}

A. Pendahuluan 460

B. Pembahasan 462

1. Kewenangan Hakim dalam Kasus Prapradilan Perkara Pidana 462

2. Akibat Hukum Apabila Putusan Hakim Bertentangan dengan Undang-Undang 467

C. Penutup 470 


\section{A. Pendahuluan}

Negara Indonesia adalah negara hukum sebagaimana disebutkan dalam Pasal 1 ayat (3) UUD NRI Tahun 1945. Muatan materi utama dari negara hukum terdiri atas: a) adanya pembatasan kekuasaan negara; b) perlindungan HAM; c) adanya peradilan yang bebas. ${ }^{1}$ Manifestasi dari negara hukum tersebut selanjutnya diterapkan di Indonesia dengan wujud amandemen UUD $1945 .^{2}$ Makna dari negara hukum sendiri yaitu negara yang berlandaskan hukum dan menjamin rasa keadilan. Rasa keadilan tersebut tercermin dari sikap para penguasa dalam menjaga stabilitas dan ketenteraman yaitu kewenangan dan tindakan alatalat perlengkapan negara atau penguasa haruslah berdasarkan hukum atau diatur oleh hukum. Hal ini menjamin keadilan dan kebebasan dalam pergaulan kehidupan bagi warganya. ${ }^{3}$

Salah satu materi negara hukum yaitu adanya peradilan yang bebas. Makna dari peradilan yang bebas sebagaimana diatur dalam Pasal 24 ayat (1) UUD NRI Tahun 1945 menyebutkan "Kekuasaan kehakiman merupakan kekuasaan yang merdeka untuk menyelenggarakan peradilan guna menegakkan hukum dan keadilan". Kekuasaan yang tidak dapat diganggu gugat oleh kekuasaan lainnya dan mengukuhkan adanya aspek kemandirian bagi aparatur pengadilannya yaitu hakim dalam mengadili suatu perkara tertentu. ${ }^{4}$

Atas dasar kebebasan tersebut hakim dalam setiap mengadili perkara diatur secara tegas dalam Pasal 10 ayat (1) UU No. 48 Tahun 2009 tentang Kekuasaan Kehakiman menetapkan bahwa "Pengadilan dilarang menolak untuk memeriksa, mengadili, dan memutus suatu perkara yang diajukan dengan dalih bahwa hukum tidak ada atau kurang jelas, melainkan wajib untuk memeriksa dan mengadilinya". Selanjutnya menurut Pasal 53 ayat (1) UU No. 48 Tahun 2009 tentang Kekuasaan Kehakiman menyatakan, "Dalam memeriksa dan memutus perkara, hakim bertanggung jawab atas penetapan dan putusan yang dibuatnya". Pengaturan Pasal 53 ayat (1) dibatasi oleh ayat (2), yaitu bahwa "Penetapan dan putusan sebagaimana dimaksud pada ayat (1) harus memuat pertimbangan hukum hakim yang didasarkan pada alasan dan dasar hukum yang tepat dan benar". ${ }^{5}$ Makna dari ketentuan Pasal 53 UU No. 48 Tahun 2009 tentang Kekuasaan Kehakiman bahwa setiap hakim dalam memeriksa suatu perkara yang telah terdaftar di pengadilan wajib memeriksa dan memutuskan perkara tersebut. Namun, hakim disatu sisi dalam menentukan putusannya harus memuat pertimbangan. Arti dari harus dalam istilah hukumnya adalah wajib yang patut untuk dilaksanakan. ${ }^{6}$

Pengadilan Negeri merupakan salah satu pelaksana kekuasaan kehakiman dalam lingkungan peradilan umum, yang memeriksa dan mengadili perkara pidana dan perdata tingkat pertama. Pasal 77 UU No. 8 Tahun 1981 tentang Hukum Acara Pidana (KUHAP) menyebutkan bahwa:

Pengadilan negeri berwenang untuk memeriksa dan memutus, sesuai dengan ketentuan yang diatur dalam undang-undang ini tentang:

a. sah atau tidaknya penangkapan, penahanan, penghentian penyidikan atau penghentian penuntutan;

b. ganti kerugian dan atau rehabilitasi bagi seorang yang perkara pidananya dihentikan pada tingkat penyidikan atau penuntutan.

Adapun tujuan dari persidangan praperadilan yaitu sebagai sarana kontrol atau pengawasan horizontal untuk menguji keabsahan penggunaan

\footnotetext{
Jimly Asshiddiqie, 2006, Pengantar Ilmu Hukum Tata Negara, Jilid I, Sekretariat Jenderal dan Kepaniteraan Mahkamah Konstitusi Republik Indonesia, Jakarta, hlm. 4.

Ibid.

Abu Daud Busro dan Abu Bakar Busro, 1985, Azas-Azas Hukum Tata Negara, Ghalia Indonesia, Jakarta, hlm 109.

Ibid., hlm. 110.

Ketentuan yang sama juga dimuat dalam Pasal 68A Undang-Undang Nomor 49 Tahun 2009 tentang Peradilan Umum (Lembaran Negara Republik Indonesia Tahun 2009 Nomor 158, Tambahan lembaran Negara Republik Indonesia Nomor 2077).

Fienso Harsono, 2010, Kamus Hukum, Vandetta Publishing, Jonggol, hlm. 36.
} 
wewenang oleh aparat penegak hukum, baik penyidik maupun penuntut umum sebagai upaya koreksi terhadap penggunaan wewenang apabila dilaksanakan secara sewenang-wenang dengan maksud/tujuan lain di luar dari yang ditentukan secara tegas dalam KUHAP guna menjamin perlindungan terhadap hak asasi setiap orang termasuk dalam hal ini Pemohon. ${ }^{7}$ Pasal 77 sampai dengan Pasal 83 KUHAP adalah suatu lembaga yang berfungsi untuk menguji apakah tindakan/ upaya paksa yang dilakukan oleh penyidik/penuntut umum sudah sesuai dengan undang-undang dan tindakan tersebut telah dilengkapi administrasi penyidikan secara cermat atau tidak, karena pada dasarnya tuntutan Praperadilan menyangkut sah tidaknya tindakan penyidik atau penuntut umum di dalam melakukan penyidikan atau penuntutan. Berdasarkan pernyataan tersebut, dapat dipahami bahwa tujuan dari lembaga praperadilan pada intinya yaitu menjunjung tinggi hak asasi manusia serta menjamin segala warganegara bersamaan kedudukannya di dalam hukum dan pemerintahan dan wajib menjunjung hukum dan pemerintahan itu dengan tidak ada kecualinya".

Sementara di sisi lain, terdapat beberapa kasus yang telah diselesaikan melalui lembaga praperadilan yang dilakukan dengan cara menafsirkan suatu undang-undang. Kasus-kasus tersebut merupakan kasus korupsi yang melibatkan beberapa petinggi aparat penegak hukum, salah satunya adalah kepolisian. Salah satu kasus korupsi yang prosesnya didaftarkan dan diselesaikan melalui lembaga praperadilan adalah kasus korupsi yang melibatkan Komisaris Jenderal Polisi Budi Gunawan. Kasus tersebut diputuskan dengan Putusan No.: 04/Pid. Prap/2015/PN.Jkt.Sel. Permasalahan yang muncul dalam pertimbangan hakim pada putusan tersebut adalah terkait bentuk penafsiran yang dilakukan oleh hakim dengan menafsirkan UU No. 2 Tahun 2002 tentang Kepolisian Negara Republik Indonesia ${ }^{8}$, UU No. 8 Tahun 1981 tentang Hukum Acara Pidana, dan UU No. 30 Tahun 2002 tentang Komisi Pemberantasan Korupsi. ${ }^{9}$ Adapun tuduhan korupsi yang disangkakan kepada Budi Gunawan adalah sebagai tersangka atas dugaan tindak pidana yang dilakukan pada saat Pemohon menjabat sebagai Kepala Biro Pembinaan Karir yang merupakan jabatan administratif dengan golongan eselon II. Dalam Putusan Nomor: 04/Pid.Prap/2015/PN.Jkt. Sel, dijelaskan bahwa golongan eselon II tidak termasuk sebagai penyelenggara negara menurut Pasal 2 angka 7 UU No. 28 Tahun 1999 tentang Penyelenggaraan Negara yang Bersih dari KKN. ${ }^{10}$ Dalam penjelasan undang-undang tersebut, dijabarkan bahwa penyelenggara negara adalah Pejabat Eselon I dan pejabat lain yang disamakan di lingkungan sipil, militer, dan Kepolisian Negara Republik Indonesia. Sebagaimana telah disampaikan bahwa jabatan Karobinkar merupakan jabatan yang dipegang oleh pejabat Eselon II, maka Karobinkar tidak termasuk dalam pengertian penyelenggara negara. ${ }^{11}$

Dalam praperadilan yang dimohonkan Komisaris Jenderal Budi Gunawan setelah ditetapkan sebagai tersangka korupsi oleh KPK, hakim yang menyidangkan permohonan praperadilannya, Sarpin Rizaldi, menyatakan, KPK tak berhak menyidik mantan calon Kapolri tersebut. ${ }^{12}$ Menurut Sarpin, Budi Gunawan bukanlah penegak hukum dan bukan penyelenggara negara karena dalam surat perintah penyidikan KPK, dia disangka melakukan korupsi saat menjabat Kepala Biro Pembinaan Karier

\footnotetext{
Maesa Plangiten, "Fungsi dan Wewenang Lembaga Praperadilan dalam Sistem Peradilan di Indonesia”, Lex Crimen, Vol. 2, No. 6, 2013. Undang-Undang Nonor 2 Tahun 2002 tentang Kepolisian Negara Republik Indonesia (Lembaran Negara Republik Indonesia Tahun 2002 Nomor 2, Tambahan Lembaran Negara Republik Indonesia Nomor 4168).

Undang-Undang Nomor 30 Tahun 2002 tentang Komisi Pemberantasan Korupsi (Lembaran Negara Republik Indonesia Tahun 2002 Nomor 137, Tambahan Negara Republik Indonesia Nomor 4250).

10 Undang-Undang Nomor 28 Tahun 1999 tentang Penyelenggaraan Negara yang Bersih dari Korupsi Kolusi Nepotisme (Lembaran Negara Republik Indonesia Tahun 1999 Nomor 75, Tambahan Lembaran Negara Republik Indonesia Nomor 3851).

11 Khaeruddin, "Penafsiran Hakim: Cara Baru Melemahkan KPK", http://print.kompas.com/baca/2015/05/29/Penafsiran-Hakim\%2c-CaraBaru-Lemahkan-Pemberantasan, diakses 8 Juni 2015.
}

12 Ibid. 
Deputi Sumber Daya Manusia Polri. ${ }^{13}$ Jabatan itu, menurut Sarpin, bukan jabatan penegak hukum dan bukan penyelenggara negara sehingga Budi tidak berhak disidik KPK. ${ }^{14}$

Selanjutnya, pada agenda sidang pembacaan putusan praperadilan tersebut, hakim Sarpin menolak seluruh eksepsi KPK dan mengabulkan permohonan Budi Gunawan. ${ }^{15}$ Sarpin memutus KPK telah melakukan penyalahgunaan wewenang (abuse of power) dalam penetapan tersangka Budi Gunawan karena dilakukan tanpa memanggil Budi Gunawan. ${ }^{16}$ Mengenai kompetensi praperadilan dalampenetapan tersangka, hakim tidak memberikan argumentasinya. Hakim hanya menjelaskan bahwa hakim dapat melakukan penafsiran hukum. ${ }^{17}$

Sehubungan dengan latar belakang tersebut di atas maka yang menjadi permasalahan untuk dibahas dalam tulisan ini adalah sebagai berikut:

Pertama, bagaimana kewenangan hakim praperadilan dalam melakukan penafsiran hukum terkait kasus tindak pidana korupsi? Kedua, apakah akibat hukum apabila putusan hakim bertentangan dengan undang-undang?

\section{B. Pembahasan}

\section{Kewenangan Hakim dalam Kasus Prapradilan Perkara Pidana}

Hakim adalah salah satu pejabat negara yang ditentukan menurut peraturan perundangundangana. Hakim diberikan kewenangan dalam memutuskan dan menyelesaikan suatu perkara. Hal tersebut menunjukkan adanya kebebasan hakim sebagaipelaksanakekuasaankehakiman. Pengadilan yang mandiri, netral (tidak memihak), kompeten, transparan, akuntabel dan berwibawa, yang mampu menegakkan wibawa hukum, pengayoman hukum, kepastian hukum dan keadilan merupakan conditio sine qua non atau persyaratan mutlak dalam sebuah negara yang berdasarkan hukum.

Meskipun telah ada dan lengkapnya pengaturan tentang kekuasaan kehakiman namun fakta hukum menunjukan adanya ketidak percayaan masyarakat pada kekuasaan kehakiman dikarenakan salah satu faktor utamanya adalah putusan-putusan hakim yang tidak mencerminkan nilai-nilai keadilan seperti yang di dambakan oleh masyarakat pencari keadilan. Hal ini tentu sangat paradoks dengan citacita dan amanat yang ingin diemban oleh kekuasaan kehakiman. ${ }^{18}$

Dalam suatu negara hukum terdapat pembatasan kekuasaan negara terhadap perseorangan. Perlindungan HAM Tersangka dilindungi dalam konstitusi dan undang-undang yang berlaku di Indonesia. Undang-Undang Dasar (UUD) 1945 yang menjadi landasan bagi seluruh warga negara Indonesia untuk mengunakan hak-haknya sebagai warga negara dalam kehidupan berbangsa dan bernegara.Jaminan konstitusi atas HAM penting artinya bagi arah pelaksanaan ketatanegaraan sebuah Negara.

Sementara itu, dengan adanya jaminan terhadap hak-hak dasar setiap warga negara mengandung arti bahwa setiap penguasa dalam negara tidak dapat dan tidak boleh bertindak sewenangwenang kepada warga negaranya, bahkan adanya hak-hak dasar itu juga mempunyai arti adanya keseimbangan dalam negara, yaitu keseimbangan antara kekuasaan dalam negara dan hak-hak dasar warga negara. Hak asasi manusia adalah hakhak yang dimiliki manusia semata-mata karena ia manusia. Umat manusia memilikinya bukan karena diberikan kepadanya oleh masyarakat atau hukum positif, melainkan semata-mata karena kodratnya sebagai manusia. ${ }^{19}$

Salah satu upaya penting yang dapat ditempuh oleh warga masyarakat, baik perseorangan maupun

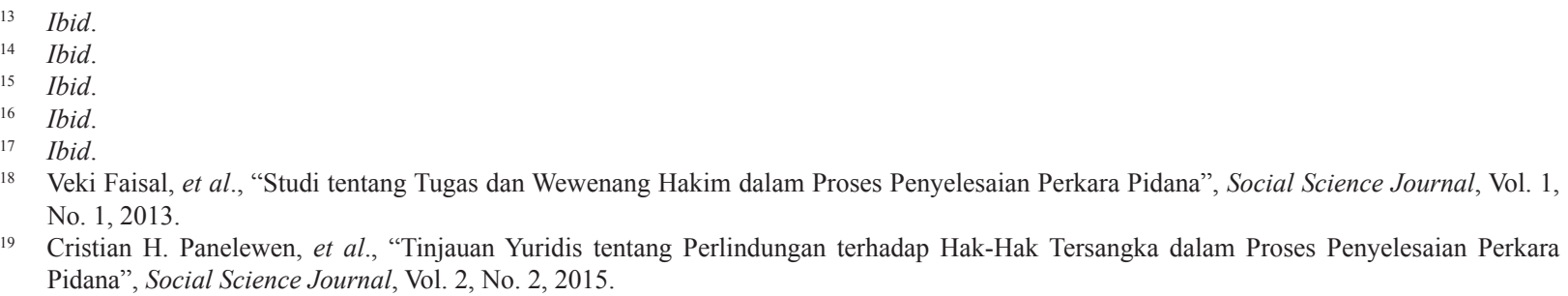


kelompok, dalam hal pemulihan hak asasinya yang telah dirugikan akibat adanya kesalahan prosedur penegakan hukum adalah melalui lembaga praperadilan. Dimana upaya paksa yang dilakukan dalam Penyidikan maupun Penuntutan oleh lembaga yang berwenang dapat dikontrol melalui Lembaga Praperadilan. Tujuan lembaga ini dibentuk agar hak-hak tersangka dapat dilindungi terutama dalam hal penangkapan maupun penahanan yang tidak sah serta adanya penghentian penyidikan maupun penuntutan. Walaupun lembaga tersebut telah diatur dalam hukum positif yakni Undang-Undang Nomor 8 Tahun 1981 namun dalam aplikasinya masih terdapat kelemahan-kelemahan baik dalam formulasinya maupun dalam penerapannya di Pengadilan sehingga tidak adanya perlindungan hak asasi manusia bagi tersangka. ${ }^{20}$ Menurut I Gede Yuliartha menyebutkan bahwa:

Pembahasan HAM terbatas dalam konteks sistem peradilan pidana (criminal justice system) yang berada dalam kerangka jaringan sistem peradilan yang mendayagunakan hukum pidana (hukum pidana materiil, hukum pidana formil dan hukum pelaksanaan pidana) kiranya tidak akan memperoleh gambaran menyeluruh dan sistemik, sehingga perlu dikaji secara utuh mencakup administrasi peradilan pidana (administration of criminal justice) yang memiliki daya jangkau lebih luas mulai dari kebijakan peradilan pidana (criminal justice policy), hak dan kewajiban serta etika penguasa dalam memperlakukan pelaku tindak pidana, saksi dan korban, berbagai pembatasan terhadap kekuasaan negara sebagai usaha menciptakan keseimbangan terhadap efisiensi dalam pencegahan dan penanggulangan kejahatan dengan jaminan terhadap hak-hak individual, tata cara mengajukan keberatan sampai dengan perlunya kerjasama internasional dalam penanggulangan kejahatan yang kwalitas dan kwantitasnya semakin meningkat, bahkan cenderung bersifat transnasional. ${ }^{21}$

Pengaturan Lembaga Praperadilan di dalam Undang-Undang Nomor 8 Tahun 1981 tentang Hukum Acara Pidana tercantum dalam Pasal 1 angka 10, Bab X Bagian Kesatu dari Pasal 77 sampai dengan Pasal 83. Pasal 1 butir 10 KUHAP menyebutkan bahwa:

Praperadilan adalah wewenang Pengadilan Negeri untuk memeriksa dan memutus menurut cara yang diatur dalam undangundang ini, tentang: ${ }^{22}$

a. Sah atau tidaknya suatu penangkapan dan atau penahanan atas permintaan tersangka atau keluarganya atau pihak lain atas kuasa tersangka;

b. Sah atau tidaknya penghentian penyelidikan atau penghentian penuntutan atas permintaan demi tegaknya hukum dan keadilan;

c. Permintaan ganti kerugian atau rehabilitasi oleh tersangka atau keluarganya atau pihak lain atas kuasanya yang perkaranya tidak diajukan ke pengadilan.

Lebih lanjut I Gede Yuliartha menegaskan dalam kesimpulan tulisannya bahwa walaupun wewenang praperadilan sebagaimana diatur dalam hukum positif terbatas, namun pada penerapannya kewenangan tersebut diperluas terhadap upaya paksa lainnya yang dilakukan oleh penyidik, dalam hal ini penyitaan dan penggeledahan, oleh karena upaya paksa tersebut berkaitan dengan pelanggaran atas hak asasi manusia. Perluasan wewenang tersebut bertujuan untuk menciptakan dan memberi rasa keadilan serta kepastian hukum bagi seseorang yang mengalami tindakan upaya paksa dari aparat penegak hukum. ${ }^{23}$

Penafsiran melalui sebuah proses peradilan (judicial interpretation) dimaknai sebagai sebuah

\footnotetext{
20 I Gede Yuliartha, 2009, Lembaga Praperadilan dalam Perspektif Kini dan Masa Mendatang dalam Hubungannya dengan Hak Asasi Manusia, Tesis, Fakultas Hukum Universitas Diponegoro, Bandung.

22 Pasal 1 angka 10, Pasal 77 sampai dengan Pasal 83 Undang-Undang Nomor 8 Tahun 1981 tentang Hukum Acara Pidana (Lembaran Negara Republik Indonesia Tahun 1982 Nomor 76, Tambahan Lembaran Negara Republik Indonesia Nomor 3209).

23 I Gede Yuliartha, Op.cit., hlm. 22.
} 
teori atau metode cara berpikir yang menjelaskan bagaimana peradilan harusnya memberikan tafsir hukum terhadap sebuah undang-undang terutama undang-undang dasar. ${ }^{24}$ Metode penafsiran tersebut bukanlah berdasarkan ketentuan baku sebagaimana dipahami secara eksakta. Penafsiran hukum bahkan disebut sebagai sebuah seni (interpretation is an art). Disebut seni karena melakukan penafsiran hukum tidak bisa melihat suatu masalah "A", maka ditafsirkan "A". Pada suatu saat penafsiran hukum bisa sangat spesifik, namun pada saat yang lain penafsiran bisa menjadi sangat abstrak bahkan "bermuka dua". ${ }^{25}$ Diperlukan banyak metode pemikiran dan alat untuk melakukan sebuah penafsiran. Upaya merangkai seluruh elemen untuk membantu sebuah penafsiran hukum yang baik itulah yang disebut seni.

Soedikno Mertokusumo juga mengemukakan bahwa terdapat metode penemuan hukum melalui penafsiran oleh hakim yaitu interpretasi gramatikal, interpretasi sitematis atau logis, interpretasi historis, interpretasi teleologis atau sosiologis. Pandangan Soedikno Mertokusumo tersebut umum digunakan dalam kaidah tafsir hukum secara umum. Namun, dalam metode tafsir konstitusi metode interpretasi yang digunakan sedikit berbeda walaupun pada intinya penafsiran hukum tersebut dapat pula digunakan untuk itu. ${ }^{26}$

Sementara itu, Zaki Ulya menyebutkan dalam tulisannya bahwa ketika hakim dihadapkan pada masalah hukum konkret yang tidak dapat disesuaikan dengan maksud pembentuk undangundang sebagaimana yang telah ditetapkan undang-undang, maka hakim dari sudut pandang semantik adalah bebas untuk menyimpang. Apakah interpretasi yang menyimpang tersebut dapat dibenarkan juga dari sudut pandang yuridis, politik hukum atau moral, hal tersebut merupakan masalah yang sama sekali tidak berhubungan. ${ }^{27}$

Peradilan umum akan menyidangkan suatu perkara dapat dilihat dari 2 (dua) sudut pandang yaitu ketika hak yang terlanggar tersebut adalah haknya negara maka subjek hukum yang melanggar akan dituntut oleh negara dan inilah yang melahirkan sistem peradilan pidana. Sedangkan jika hak yang terlanggar tersebut adalah haknya orang maka yang akan mempertahankan hak yang terlanggar itu adalah orang yang merasa dirugikan tadi atau haknya telah terlanggar tadi, inilah yang disebut dengan sistem peradilan perdata. Pembedaan tersebut dilihat dari sudut pihak yang dirugikan. Jika negara yang dirugikan maka yang menuntut adalah negara, sebalikya jika orang yang dirugikan maka orang tersebut yang akan mempertahankan haknya. ${ }^{28}$

Adapun salah satu kasus yang memposisikan satu pihak dirugikan dalam proses hukum dan hakim memutuskan perkara tersebut dengan menggunakan metode penafsiran hukum yaitu perkara praperadilan Komisaris Jenderal (pol) Budi Gunawan. Kasus tersebut diawali dengan adanya upaya penangkapan oleh KPK terhadap Komjen (pol) Budi Gunawan. Hakim Sarpin yang menjadi hakim praperadilan tersebut menggunakan beberapa metode penafsiran hukum yang dikeluarkan sebagai pertimbangan hukum dalam memuat amar putusan. Beberapa poin penting pada Putusan Nomor: 04/ Pid.Prap/2015/PN.Jkt.Sel, yaitu:
a. bahwa kewenangan KPK perlu melihat UU KPK;
b. bahwa penetapan Tersangka saat Budi Gunawan menjabat sebagai Karo- binkar;
c. bahwa apakah pemohon (tersangka) sebagai Karobinkar, dalam hal ini masuk sebagai subjek dalam Tindak Pidana Korupsi sebagaimana wewe-

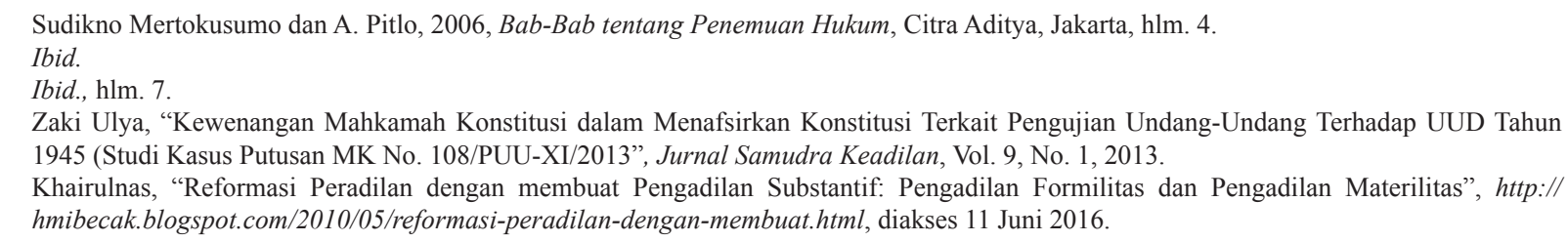


nang KPK;

d. menurut penjelasan dari POLRI, Karobinkar masuk unsur pelaksana SDM sebagai unsur pembantu pimpinan dan staf manajemen SDM;

e. bahwa jabatan Karobinkar adalah jabatan administrasi yakni eselon 2;

f. bahwa jabatan karobinkar bukan penyelenggara negara karena bukan eselon 1;

g. bahwa termohon buktikan tersangka sebagai penyelenggara negara dan sudah ada dua alat bukti;

h. bahwa termohon tidak bisa buktikan Budi Gunawan sebagai subjek TP korupsi;

i. bahwa perbuatan menerima hadiah/ janji tidak dikaitkan dengan kerugian negara. Hal ini karena tidak menyebabkan adanya kerugian negara ehingga kualifikasi tersangka dalam hal ini tidak terpenuhi;

j. bahwa pemohon bukan subjek pelaku tindak pidana korupsi oleh karenanya proses penyidikan yang dilakukan oleh KPK terhadap pemohon tidak sah sehingga tidak ada kekuatan hukum yang mengikat;

k. karena penetapan tidak sah maka sprindik tidak sah, tidak berdasar hukum, oleh karenanya tidak ada kekuatan hukum yang mengikat;

1. bahwa oleh karena penetapan Tersangka tidak sah, maka penetapan tersangka kepada pemohon harus dinyatakan tidak sah. ${ }^{29}$

Pernyataan hakim Sarpin dalam pertimbangan putusannya pada intinya menyebutkan pemohon tidak merupakan sebagai subjek penyidikan oleh KPK. Namun, menurut UU No. 30 Tahun 2002 tentang KPK menentukan secara jelas bahwa setiap penyelenggara negara/ aparatur hukum yang melakukan korupsi dengan kriteria jumlah tertentu dapat dijadikan sebagai subjek KPK. Yusi Amdani dalam tulisannya menyebutkan bahwa secara yuridis kewenangan KPK secara jelas dimuat dalam Pasal 11 Undang-Undang No. 30 Tahun 2002 tentang
KPK, yaitu: (a) KPK berhak menangani perkaraperkara yang melibatkan aparat penegak hukum atau penyelenggara Negara; (b) mendapat perhatian dan meresahkan masyarakat; (c) merugikan negara minimal 1 milyar rupiah.

Apabila dikaji lebih lanjut, makna dari penyelenggara negara telah disebutkan dalam Pasal 1 angka 1 UU No. 28 Tahun 1999 tentang Penyelenggaraan Negara yang Bersih dari KKN, bahwa "Penyelenggara Negara adalah Pejabat Negara yang menjalankan fungsi eksekutif, legislatif, atau yudikatif dan pejabat lain yang fungsi dan tugas pokoknya berkaitan dengan penyelenggaraan negara sesuai dengan ketentuan peraturan perundang-undangan yang berlaku”. Kemudian, di dalam Pasal 2 UU No. 28 Tahun 1999 dijelaskan bahwa penyelenggara negara adalah: ${ }^{30}$
a. Pejabat Negara pada Lembaga Ter- tinggi Negara;
b. Pejabat Negara pada Lembaga Tinggi Negara;
c. Menteri;
d. Gubernur;
e. Hakim;
f. Pejabat negara yang lain sesuai dengan ketentuan peraturan perundang-un- dangan yang berlaku; dan
g. Pejabat lain yang memiliki fungsi strategis dalam kaitannya dengan penyelenggara negara sesuai dengan ketentuan peraturan perundang-un- dangan yang berlaku.

Kemudian pengertian pegawai negeri dan pejabat negara diatur dalam UU No. 43 Tahun 1999 tentang Perubahan Atas UU No. 8 Tahun 1974 tentang Pokok-Pokok Kepegawaian yang menyebutkan bahwa:

Pegawai Negeri adalah setiap warga negara Republik Indonesia yang telah memenuhi syarat yang ditentukan, diangkat oleh pejabat yang berwenang dan diserahi tugas dalam suatu jabatan negeri, atau diserahi tugas negara lainnya, dan digaji berdasarkan per-

\footnotetext{
Data diolah oleh Penulis.

30 Undang-Undang Nomor 28 Tahun 1999 tentang Penyelenggaraan Negara yang Bersih dari Korupsi Kolusi Nepotisme (Lembaran Negara Republik Indonesia Tahun 1999 Nomor 75, Tambahan Lembaran Negara Republik Indonesia Nomor 3851).
} 
aturan perundang-undangan yang berlaku. ${ }^{31}$

Pejabat Negara adalah pimpinan dan anggota lembaga tertinggi/tinggi negara sebagaimana dimaksud dalam Undang-Undang Dasar 1945 dan Pejabat Negara lainnya yang ditentukan oleh Undang-undang. ${ }^{32}$

Selanjutnya, dalam Pasal 2 ayat (1) UU No. 43 Tahun 1999 dijelaskan bahwa pegawai negeri terdiri dari: ${ }^{33}$

a. Pegawai Negeri Sipil;

b. Anggota Tentara Nasional Indonesia; dan

c. Anggota Kepolisian Negara Republik Indonesia.

Menyimak dari seluruh aturan hukum tentang penyelenggaraan negara di atas dan dihubungkan dengan Putusan No. 04/Pid.Prap/2015/PN.Jkt. Sel, maka dapat disimpulkan dengan jelas bahwa Komjen (pol) Budi Gunawan bukan sebagai subjek penyidikan KPK adalah kesalahan. Apabila ditinjau dari Pasal 2 ayat (1) huruf $\mathrm{c}$ di atas, jelas bahwa Pejabat yang berada dalam lingkungan Kepolisian Negara Republik Indonesia merupakan salah satu unsur dari penyelenggara negara. Hal ini dapat dilihat dari makna kata "anggota" pada huruf c di atas yaitu seluruh komponen keanggotaan kepolisian yang berada dalam intansi Polri baik individu yang menjabat jabatan karir administrasi maupun profesi sebagai penyidik menurut KUHAP merupakan unsur dari pegawai negeri. Oleh karena itu, apabila adanya indikasi dari penyelenggara negara sebagaimana dimaksud di atas melakukan tindak pidana korupsi, maka seyogyanya merupakan subjek tindak pidana korupsi yang dapat disidik oleh KPK menurut Pasal 11 huruf a UU No. 30 Tahun 2002 tentang KPK.

Selanjutnya menurut pendapat Bernard Arief Sidharta, yang juga dipanggil sebagai ahli hukum dari pihak KPK menyebutkan bahwa pendapatnya yang dipaparkan dalam persidangan Praperadilan Budi Gunawan disalahartikan oleh Hakim Sarpin. Pandangan Arief Sidharta terkait kasus tersebut didasarkan pada Pasal 77 KUHAP. Dalam pasal itu yang bisa ditangani oleh Praperadilan itu telah diatur secara limitatif, hanya untuk sah atau tidaknya penangkapan, penahanan, penghentian penyidikan atau penghentian penuntutan, ganti kerugian dan atau rehabilitasi bagi seorang yang perkara pidananya dihentikan pada tingkat penyidikan atau penuntutan. Di dalam pasal tersebut jelas tidak disebut kewenangan untuk penetapan tersangka sehingga seharusnya permohonan Budi Gunawan ditolak oleh hakim. ${ }^{34}$

Selanjutnya menurut beliau, dalam hukum pidana itu berlaku asas legalitas, yaitu asas yang bisa mengikat orang itu hanya yang tercantum dalam undang-undang. ${ }^{35}$ Juga dalam hukum acara pidana sebagai hukum prosedural yang mengatur tentang bagaimana hukum pidana materil dilaksanakan, itu tidak dapat disimpangi dan harus diberlakukan secara ketat. ${ }^{36}$ Oleh karena itu interpretasi yang dapat digunakan untuk menafsirkan pasal sangat terbatas pada interpretasi gramatikal dan sistematis, atau yang paling jauh secara historis dan teleologis dilihat dari tujuan yang ingin dicapai. ${ }^{37}$

Dalam hukum acara sama sekali tidak dapat dilakukan penafsiran karena ketentuan yang ada di dalamnya sangat limitatif atau jelas. Dalam hukum pidana sendiri pun penafsiran dibatasi,

\footnotetext{
31 Pasal 1 angka 9 Undang Nomor 43 Tahun 1999 tentang Perubahan Atas Undang-Undang Nomor 8 Tahun 1974 tentang Pokok-Pokok Kepegawaian (Lembaran Negara Republik Indonesia Tahun 1999 Nomor 169, Tambahan Lembaran Negara Republik Indonesia Nomor 3890).

32 Pasal 1 angka 4 Undang-Undang Nomor 43 Tahun 1999 tentang Perubahan Atas Undang-Undang Nomor 8 Tahun 1974 tentang Pokok-Pokok Kepegawaian (Lembaran Negara Republik Indonesia Tahun 1999 Nomor 169, Tambahan Lembaran Negara Republik Indonesia Nomor 3890).

33 Undang-Undang Nomor 43 Tahun 1999 tentang Perubahan Atas Undang-Undang Nomor 8 Tahun 1974 tentang Pokok-Pokok Kepegawaian (Lembaran Negara Republik Indonesia Tahun 1999 Nomor 169, Tambahan Lembaran Negara Republik Indonesia Nomor 3890).

34 Bernard Arief Sidharta, "Sarpin Salah Mengartikan Pendapat Saya", http://www.sorgemagz.com/?p=5512\#.VXmfF7WADa0, diakses 11 Juni 2015.

35 Ibid.

36 Ibid.

37 Ibid.
} 
hanya penafsiran ekstensif saja yang dapat dilakukan. Metode penafsiran analogis dan juga pengkonstruksian hukum itu tidak diperkenankan dalam hukum pidana sehingga dapat disimpulkan bahwa hukum Pidana melarang analogi. Lebih lanjut lagi pemaparan Arief Sidharta menyebutkan bahwa proses penemuan hukum yang dilakukan oleh Hakim Sarpin terhadap permohonan Budi Gunawan bahwa seharusnya hakim praperadilan tidak dapat melakukan penafsiran hukum dan menemukan kaedah baru karena hal tersebut bukanlah kewenangan hakim praperadilan. ${ }^{38}$

Atas dasar tersebut, maka dapat ditekankan bahwa hakim praperadilan selayaknya hanya berwenang mengadili dan memutuskan perkara sebagaimana diatur dalam Pasal 77 KUHAP. Inti dari pasal tersebut hanya mengatur mengenai prosedur penyelidikan dan penyidikan yang dirasakan merugikan pemohon. Oleh karena itu, karena aspeknya adalah prosedural maka sudah tentu hakim yang mengadili perkara praperadilan tidak diperbolehkan melakukan penafsiran hukum atau menemukan suatu kaedah hukum yang baru. Berdasarkan hal tersebut, maka Putusan No.: 04/ Pid.Prap/2015/PN.Jkt terkait permohonan Budi Gunawan terhadap KPK merupakan sebuah preseden buruk dalam lembaga peradilan.

\section{Akibat Hukum Apabila Putusan Hakim Bertentangan dengan Undang-Undang}

Konsep penafsiran hukum terhadap suatu undang-undang telah dikenal di Indonesia dan hanya dilakukan menurut peraturan perundangundangan oleh hakim. Secara garis besar penafsiran hukum terhadap peraturan perundang-undangan dapat ditempuh melalui mekanisme judicial review. Adapun pelaksana kekuasaan kehakiman yang dapat melakukan judicial review dengan penafsiran hukum adalah Mahkamah Agung dan Mahkamah Konstitusi. Pengujian tersebut dengan mengkaji suatu aturan hukum yang dinilai bertentangan dengan aturan hukum yang lebih tinggi.
Batasan kewenangan Mahkamah Agung dan Mahkamah Konstitusi hanya pada jenis hirarkhis peraturan perundang-undangan. Mahkamah Agung menurut Pasal 24A UUD NRI Tahun 1945 berhak menguji peraturan perundang-undangan terhadap undang-undang. Sedangkan Mahkamah Konstitusi berwenang menguji undang-undang terhadap UUD NRI Tahun 1945 sebagaimana ditetapkan dalam Pasal 24C UUD NRI Tahun 1945. Oleh karena itu, hakim yang dapat melakukan penafsiran terhadap peraturan perundang-undangan hanyalah hakim agung dan hakim konstitusi.

Selanjutnya, bagaimana dengan kewenangan hakim yang berada di bawah lingkungan Mahkamah Agung? Sebagaimana ditentukan dalam Pasal 5 ayat (1) UU No. 48 Tahun 2009 tentang Kekuasaan Kehakiman menyebutkan bahwa "Hakim dan hakim konstitusi wajib menggali, mengikuti, dan memahami nilai-nilai hukum dan rasa keadilan yang hidup dalam masyarakat".

Berpijak dari Undang-Undang tersebut maka dalam mengadili suatu perkara yang dihadapinya hakim akan bertindak sebagai berikut: ${ }^{39}$

a. dalam kasus yang hukumnya atau undang-undangnya sudah jelas tinggal menerapkan saja hukumnya;

b. dalam kasus yang hukumnya tidak atau belum jelas maka hakim akan menafsirkan hukum atau UndangUndang melalui metode penafsiran yang lazim berlaku dalam ilmu hukum;

c. dalam kasus yang belum ada UndangUndang atau hukum tertulis yang mengaturnya, maka hakim harus menemukan hukumnya dengan menggali dan mengikuti nilai-nilai hukum yang hidup dalam masyarakat.

Pada akhirnya hakim harus memutuskan perkara yang diadilinya semata-mata berdasarkan hukum, kebenaran dan keadilan dengan tiada membeda-bedakan orang dengan pelbagai resiko

\footnotetext{
38 Dhani Irawan, “Arief Sidharta Akan ke KY, Jelaskan Kekeliruan Sarpin yang Kutip Pendapatnya”, http://news.detik.com/read/2015/02/25/08 1804/2842178/10/arief-sidharta-akan-ke-ky-jelaskan-kekeliruan-sarpin-yang-kutip-pendapatnya, diakses 11 Juni 2015.

39 Sudikno Mertokusumo, 2001, Penemuan Hukum Sebuah Pengantar, Liberty, Yogyakarta, hlm. 33.
} 
yang dihadapinya supaya putusan hakim diambil secara adil dan obyektif berdasarkan hukum, kebenaran dan keadilan. Selain itu, pemeriksaan oleh hakim harus dilakukan dalam sidang yang terbuka untuk umum (kecuali Undang-Undang menentukan lain), juga hakim wajib membuat pertimbangan-pertimbangan hukum yang dipergunakan untuk memutus perkaranya. Demi mencegah subyektivitas seorang hakim, maka Pasal 5 UU No. 48 Tahun 2009 menentukan bahwa hakim wajib menggali, mengikuti dan memahami nilai-nilai hukum yang hidup dalam masyarakat. Namun tentu saja menggali dan menemukan nilai-nilai hukum yang baik dan benar yang sesuai dengan Pancasila dan "According to the law of civilizied nations". ${ }^{40}$

Kegunaan dari penemuan hukum adalah mencari dan menemukan kaidah hukum yang dapat digunakan untuk memberikan keputusan yang tepat atau benar, dan secara tidak langsung memberikan kepastian hukum juga didalam masyarakat. Sementara itu, kenyataan menunjukkan bahwa: ${ }^{41}$

a. adakalanya pembuat Undang-undang sengaja atau tidak sengaja menggunakan istilah-istilah atau pengertian pengertian yanga sangat umum sifatnya sehingga dapat diberi lebih dari satu pengertian atau pemaknaan;

b. adakalanya istilah, kata, pengertian, kalimat yang digunakan di dalam peraturan perundang-undangan tidak jelas arti atau maknanya, atau tidak dapat diwujudkan lagi dalam kenyataan sebagai akibat adanya perkembanganperkembangan didalam masyarakat;

c. adakalanya terjadi suatu masalah yang tidak ada peraturan perudangundangan yang mengatur masalah tersebut.

Dalam menghadapi kemungkinan-kemungkinan itulah seorang hakim atau pengemban profesi hukum lainnya harus dapat menemukan dan juga menentukan apa yang dapat dijadikan hukum dalam rangka pembuatan keputusan hukum atau menyelesaikan masalah hukum yang sedang dihadapi.

Berdasarkan kajian penemuan hukum yang telah dipaparkan di atas, dapat dipahami bahwa Putusan Nomor: 04/Pid.Prap/2015/PN.Jkt.Sel yang telah diputuskan di depan persidangan terbuka untuk umum, antara Budi Gunawan dan KPK telah dilakukan penafsiran hukum. Adapun penafsiran yang dilakukan oleh hakim dalam putusan tersebut adalah menafsirkan beberapa ketentuan undangundang yang sudah jelas pengaturannya, yaitu UU No. 2 Tahun 2002 tentang Kepolisian Negara Republik Indonesia, UU No. 30 Tahun 2002 tentang Komisi Pemberantasan Korupsi, dan KUHAP.

Hakim Sarpin berpendapat sidang praperadilan dapat memutus keabsahan penetapan tersangka. Menurut Sarpin, KPK tak berwenang menetapkan Budi Gunawan sebagai tersangka. Sarpin dinilai mendistorsi penjelasan Arief Sidharta. Apabila merujuk Pasal 77 KUHAP, praperadilan hanya berwenang memeriksa sah atau tidak penangkapan dan penahanan; sah atau tidak penghentian penyidikan atau penghentian penuntutan; dan ganti kerugian dan rehabilitasi bagi seseorang yang perkaranya dihentikan pada tingkat penyidikan dan penuntutan.

Pendapat hakim Sarpin dalam putusannya di atas mengakibatkan terjadinya pertentangan antara para pakar hukum. Hal ini menimbulkan kekhawatiran karena putusan tersebut akan menjadi yurisprudensi dan dijadikan sebagai sumber hukum bagi hakim dalam menyikapi kasus yang sama. Kekhawatiran tersebut mengindikasikan legalitas pra-peradilan lah yang berhak menentukan tersangka ataukah tidak. Sebagaimana dipaparkan oleh Busyro Muqoddas bahwa Mahkamah Agung merupakan pihak yang paling bertanggung jawab untuk menghentikan banyaknya permohonan praperadilan terkait penetapan tersangka. ${ }^{42}$ Adapun

40 Sutioso, 2006, Metode Penemuan Hukum, Universitas Islam Indonesia Press, Yogyakarta, hlm. 10.

41 H.J. Van Eikema Hommes, disadur oleh B. Arief Sidharta, 2004, Hubungan Aspek Hukum dan Aspek Kehidupan Lain, Laboratorium Fakultas Hukum Universitas Katolik Parahyangan, Bandung, hlm. 1. 
alasan yang dikemukakan Busyro Muqoddas yaitu maraknya sejumlah tersangka kasus korupsi yang mengajukan praperadilan. ${ }^{43}$ Lebih lanjut beliau berpendapat bahwa Mahkamah Agung sebagai lembaga peradilan tertinggi harus segera mengambil sikap. ${ }^{44}$ Jika tidak, maka tak bisa dihindari semakin banyak tersangka korupsi yang menggugat penetapan statusnya. ${ }^{45}$

Pendapat yang kontra didasarkan pada bab X Praperadilan, Pasal 77 UU No. 8 Tahun 1981 tentang KUHAP. Pasal itu hanya mengatur kewenangan praperadilan terbatas pada sah tidaknya penangkapan, penahananan, penghentian penyidikan atau penghentian penuntutan, termasuk pemberian ganti rugi dan rehabilitasi terhadap orang yang dirugikan. Dalam teksnya, tidak menyebut tersangka sehingga dinilai melebihi dari kewenangannya dalam menafsirkan pasal undang-undang tersebut. Aliran seperti itu dalam ilmu hukum disebut mazhab positivisme yang juga sudah berkembang sejak abad ke-18 dengan tokoh utamanya Hans Kelsen yang merupakan pemikir hukum dari Jerman dengan didukung oleh para sarjana lainnya seperti John Austin dan H.L.A. Hart. Mereka menyebutkan bahwa hukum jangan dicampuradukkan dengan konfigurasi politik, agama dan moral. Hukum positif harus dijalankan sesuai dengan teksnya.

Inti utama dari mazhab positivisme yaitu tidak dapat ditafsirkan berbeda di luar teks yang dikehendaki penguasaannya. Hal itu akan menjadi masalah ketika para penegak hukum mencampuradukkan antara kepentingan kelompok dengan teks hukum. Dengan begitu hukum positif atau hukum murni, tak dapat dilaksanakan lantaran sudah adanya niat "jahat" atau terkontaminasi dari para penegak hukum itu.

Mahkamah Agung dapat mengawasi putusan praperadilan apabila putusan itu bertentangan dengan undang-undang dan dapat merusak tatanan hukum di Indonesia. Hal ini sesuai dengan Pasal 32 ayat (3) dan (4) UU No. 3 Tahun 2009 tentang Mahkamah Agung yang menyatakan bahwa "Mahkamah Agung berwenang untuk meminta keterangan tentang hal-hal yang bersangkutan dengan teknis peradilan dari semua badan peradilan yang berada di bawahnya dan memberi petunjuk, teguran, atau peringatan kepada pengadilan di semua badan peradilan yang berada di bawahnya".

Adapun kekhawatiran lainnya dengan dikabulkannya putusan praperadilan ini berpotensi membuka pintu upaya hukum yang luas bagi para tersangka yang telah ditetapkan oleh KPK sehingga "marwah" KPK yang sebelumnya ditakuti oleh para koruptor namanya kini luntur dengan kejadian pra peradilan Budi Gunawan. Selanjutnya, jika merasa tidak puas terhadap putusan hakim Sarpin yang final dan mengikat, masyarakat luas dapat mengadukan perilaku Sarpin kepada Komisi Yudisial (KY). Ini dapat dilakukan untuk menguji apakah Sarpin telah melanggar code of conduct dan unprofessional conduct sesuai dengan kode etik hakim yang berlaku. ${ }^{46}$

Ahli hukum administrasi negara Riawan Tjandra menyatakan seyogyanya Mahkamah Agung merespon pro dan kontra yang timbul akibat putusan praperadilan Budi Gunawan. Putusan tersebut menurutnya telah menimbulkan ketidakseragaman. Ia juga menambahkan bahwa sudah ada beberapa kasus dan telah diputuskan menolak praperadilan. Dua putusan tersebut terjadi di Purwokerto dan di Jakarta untuk kasus Sutan Bhatoegana. Penolakan terhadap kedua praperadilan tersebut menunjukkan bahwa putusan praperadilan Jakarta Selatan terkait penetapan tersangka Budi Gunawan tidak layak dijadikan sebagai yurisprudensi di lingkungan

\footnotetext{
42 Ibid.

43 Busyro Muqoddas, "MA Bertanggung Jawab Luruskan Putusan Hakim Sarpin", http://nasional.news.viva.co.id/news/read/602120-mabertanggung-jawab-luruskan-putusan-hakim-sarpin, diakses 12 Juni 2012. 
pengadilan sendiri. ${ }^{47}$

Dampak dari putusan hakim Sarpin membuat beberapa tersangka lainnya ikut mengajukan praperadilan, seperti Sutan Bhatoegana yang ditetapkan tersangka oleh KPK. Lalu, di Purwokerto, Jawa Tengah, Majelis Hakim menolak gugatan praperadilan dugaan korupsi dana bantuan sosial Kementerian Pertanian, dimana kedua pengadilan tersebut mempunyai dasar pertimbangan hukum yang berbeda dengan hakim Sarpin sehingga menolak perkara gugatan praperadilan tersebut.

\section{Penutup}

Berdasarkan Putusan Nomor 04/Pid. Prap/2015/PN.Jkt.Sel terkait sidang praperadilan atas penetapan tersangka Komjen(pol) Budi Gunawan oleh KPK, Hakim Sarpin Rizaldi telah melakukan penafsiran hukum terhadap beberapa ketentuan undang-undang. Secara konseptual hukum, penafsiran yang dilakukan oleh hakim Sarpin adalah salah, dikarenakan aturan yang telah ditafsirkan merupakan aturan yang jelas dan juga hanya terkait tentang prosedural hukum acara. Putusan Sarpin dalam posisinya sebagai hakim Praperadilan yang memberi penekanan terhadap status Budi Gunawan yang bukan pejabat Negara dan dianggap tidak merugikan keuangan negara, secara hukum telah melampaui batas kewenangan (ultra petita). Tindakan melampaui kewenangan hukum inilah yang merupakan salah satu praktik penyebab rusaknya struktur dan sistem peradilan di Indonesia. Atas dasar putusan praperadilan tersebut ultra petita maka dapat diajukan kasasi ke Mahkamah Agung oleh KPK, guna dilakukan peninjauan terhadap putusan praperadilan dengan dasar Pasal 88 KUHAP.

Adapun dampak yang diakibatkan adanya putusan prapradilan Nomor 04/Pid.Prap/2015/ PN.Jkt.Sel yaitu munculnya kekhawatiran para pakar hukum putusan tersebut akan dijadikan yurisprudensi oleh hakim lainnya dalam menangani kasus praperadilan. Selain itu, akibat adanya putusan praperadilan tersebut dapat membuka peluang bagi pihak koruptor yang telah ditetapkan tersangka dan sedang menjalani proses hukum di KPK, turut mengajukan gugatan praperadilan sebagai jalur hukumnya. putusan praperadilan yang memenangkan gugatan calon Kapolri Komisaris Jenderal Budi Gunawan di Pengadilan Negeri Jakarta Selatan, mengucilkan ketentuan hukum dan perundang-undangan yang ada.

\section{DAFTAR PUSTAKA}

\section{A. Buku}

Asshiddiqie, Jimly, 2006, Pengantar Ilmu Hukum Tata Negara, Sekretariat Jenderal dan Kepaniteraan Mahkamah Konstitusi Republik Indonesia, Jakarta.

Busro, Abu Daud dan Abu Bakar Busro, 1985, AzasAzas Hukum Tata Negara, Ghalia Indonesia, Jakarta.

Harsono, Fienso, 2010, Kamus Hukum, Vandetta Publishing, Jonggol.

Mertokusumo, Sudikno dan A. Pitlo, 2006, BabBab tentang Penemuan Hukum, Citra Aditya, Jakarta.

\section{B. Artikel Jurnal}

Faisal, Veki, et al., "Studi tentang Tugas dan Wewenang Hakim dalam Proses Penyelesaian Perkara Pidana”, Social Science Journal, Vol. 1, No. 1, 2013.

Panelewen, Cristian H., et al., "Tinjauan Yuridis Tentang Perlindungan terhadap Hak-Hak Tersangka dalam Proses Penyelesaian Perkara Pidana”, Social Science Journal, Vol. 2, No. 2, 2015.

Plangiten, Maesa, "Fungsi dan Wewenang Lembaga Praperadilan dalam Sistem Peradilan di Indonesia", Lex Crimen, Vol. 2, No. 6, 2013.

47 Riawan Tjandra, “Tidak Seragam, Putusan Sarpin Sulit Dijadikan Yurisprudensi”, http://www.gresnews.com/berita/hukum/01313-takseragam-putusan-sarpin-sulit-jadi-yurisprudensi/, diakses 12 Juni 2015. 
Ulya, Zaki, "Kewenangan Mahkamah Konstitusi dalam Menafsirkan Konstitusi Terkait Pengujian Undang-Undang terhadap UUD Tahun 1945 (Studi Kasus Putusan MK No. 108/PUU-XI/2013)", Jurnal Samudra Keadilan, Vol. 9, No. 1, 2013.

\section{Hasil Penelitian/Tugas Akhir}

Yuliartha, I Gedhe, 2009, Lembaga Praperadilan dalam Perspektif Kini dan Masa Mendatang dalam Hubungannya dengan Hak Asasi Manusia, Tesis, Fakultas Hukum Universitas Diponegoro, Bandung.

\section{Internet}

Khaeruddin, "Penafsiran Hakim: Cara Baru Melemahkan KPK", http://print.kompas.com/ baca/2015/05/29/Penafsiran-Hakim\%2cCara-Baru-Lemahkan-Pemberantasan, diakses 8 Juni 2015.

Khairulnas, "Reformasi Peradilan dengan membuat Pengadilan Substantif: Pengadilan Formilitas dan Pengadilan Materilitas", http://hmibecak. blogspot.com/2010/05/reformasi-peradilandengan-membuat.html, diakses 11 Juni 2016.

Sidharta, Bernard Arif, "Sarpin Salah Mengartikan Pendapat Saya", http://www.sorgemagz. $\mathrm{com} / ? p=5512 \#$.VXmfF7WADa0, diakses 11 Juni 2015.

Irawan, Dhani, "Arief Sidharta Akan ke KY, Jelaskan Kekeliruan Sarpin yang KutipPendapatnya", http://news.detik. $\mathrm{com} / \mathrm{read} / 2015 / 02 / 25 / 081804 / 284217 /$ 10/arief-sidharta-akan-ke-ky-jelaskankekeliruan-sarpin-yang-kutip-pendapatnya, diakses 11 Juni 2015.

Muqoddas, Busyro, "MA Bertanggung Jawab Luruskan Putusan Hakim Sarpin, Akibat putusan Sarpin, Banyak Tersangka Korupsi Menggugat KPK”, http://nasional.news.viva. co.id/news/read/602120-ma-bertanggungjawab-luruskan-putusan-hakim-sarpin, diakses 12 Juni 2012.

Indraarahmatullah, "Analisis Putusan Pra Peradilan Budi Gunawan", https://indrarahmatullah. wordpress.com/2015/02/18/analisisputusan-pra-peradilan-budi-gunawan/, diakses 12 Juni 2012.

Tjandra, Riawan, "Tidak Seragam, Putusan Sarpin Sulit Dijadikan Yurisprudensi", http:// www.gresnews.com/berita/hukum/01313tak-seragam-putusan-sarpin-sulit-jadiyurisprudensi/, diakses 12 Juni 2015.

\section{E. Peraturan Perundang-undangan}

Undang-Undang Nonor 2 Tahun 2002 tentang Kepolisian Negara Republik Indonesia (Lembaran Negara Republik Indonesia Tahun 2002 Nomor 2, Tambahan Lembaran Negara Republik Indonesia Nomor 4168).

Undang-Undang Nomor 30 Tahun 2002 tentang Komisi Pemberantasan Korupsi (Lembaran Negara Republik Indonesia Tahun 2002 Nomor 137, Tambahan Negara Republik Indonesia Nomor 4250).

Undang-Undang Nomor 28 Tahun 1999 tentang Penyelenggaraan Negara yang Bersih dari Korupsi Kolusi Nepotisme (Lembaran Negara Republik Indonesia Tahun 1999 Nomor 75, Tambahan Lembaran Negara Republik Indonesia Nomor 3851).

Undang-Undang Nomor 49 Tahun 2009 tentang Peradilan Umum (Lembaran Negara Republik Indonesia Tahun 2009 Nomor 158, Tambahan lembaran Negara Republik Indonesia Nomor 2077).

Undang-Undang Nomor 8 Tahun 1981 tentang Hukum Acara Pidana (lembaran Negara Republik Indonesia Tahun 1982 Nomor 76, Tambahan Lembaran Negara Republik Indonesia Nomor 3209).

\section{F. Putusan Pengadilan}

Putusan Prapradilan Nomor 04/Pid.Prap/2015/ PN.Jkt.Sel perihal Perkara Praperadilan yang diajukan oleh Komisaris Jenderal Polisi Budi Gunawan Terhadap Komisi Pemberantasan Korupsi Atas Penetapan Status Tersangka Komisaris Jenderal Polisi Budi Gunawan, tanggal 16 Februari 2015. 